\title{
Geographical distribution and seasonal and diel changes in the diversity of calanoid copepods in the North Atlantic and North Sea
}

\author{
Grégory Beaugrand $^{1,2, *}$, Frédéric Ibañez ${ }^{2}$ J. Alistair Lindley ${ }^{1}$ \\ ${ }^{1}$ Sir Alister Hardy Foundation for Ocean Science, The Laboratory, Citadel Hill, Plymouth PL1 2PB, United Kingdom \\ ${ }^{2}$ Observatoire Océanologique, Laboratoire d'Océanologie Biologique et Écologie du Plancton Marin, BP 28, \\ 06230 Villefranche sur mer, France
}

\begin{abstract}
This paper examines spatial distribution in the pelagic diversity of calanoid copepods in the North Atlantic and the North Sea, taking into account changes at seasonal and diel scales. Based on 40 yr of sampling by the Continuous Plankton Recorder (CPR) survey, the diversity (as number of taxa) was estimated on a regular grid for each month and time of day. Principal components analysis (PCA) allowed spatial decomposition of diversity, detection of major seasonal and diel patterns, the location of regions where these occur, and finally the modelling of temporal changes at seasonal and diel scales. The results underline the importance of hydrography and topography in the regulation of pelagic diversity. By considering these abiotic factors and the characteristics of seasonal and diel changes in diversity, a partition of the North Atlantic and the North Sea is proposed. This demonstrates the importance of the warm North Atlantic Current and the continental slope currents and undercurrents along the European Continental Shelf. It is suggested that modification in the path or intensity of these currents could imply marked changes in the structure and functioning of ecosystems west and north of the British Isles.
\end{abstract}

KEY WORDS: Pelagic diversity $\cdot$ Calanoid copepods $\cdot$ Spatial distribution $\cdot$ Seasonal variations $\cdot$ Diel changes · Continuous Plankton Recorder (CPR) survey

\section{INTRODUCTION}

Knowledge about geographical distribution of plankton in the northern North Atlantic has been intensively documented from the Continuous Plankton Recorder (CPR) survey (Edinburgh Oceanographic Laboratory 1973). Seasonal and year-to-year fluctuations of plankton have also largely been investigated (e.g. Colebrook 1984, Lindley 1987, Reid et al. 1998, Beaugrand et al. 2000a). On the other hand, little attention has been devoted to the analysis of spatial changes in pelagic diversity at various temporal scales, and the literature on this remains scarce (Lindley 1998, Beau-

*E-mail: gbea@wpo.nerc.ac.uk grand et al. 2000b). Nevertheless, this diversity is a key biological property of the structure and function of ecosystems.

Examination of biodiversity at the scale of the North Atlantic should take into consideration that presentday geographic distribution patterns have been established at many scales (Angel 1997). At the geological scale, events such as continental drift have led to the opening or closure of sea ways and modification of oceanic circulation. Insolation variations at the Earth's surface resulting from orbital forcing (e.g. Milankovitch cycles) have a large influence on the climate and may have played an important role in the origin of large-scale patterns in biodiversity (Crame 1993, Molfino 1994). These large-scale factors are probably responsible for the polar-tropical difference in the num- 
ber of species reported in the literature (e.g. Ruddiman 1969, Rex et al. 1993, Rosenzweig 1995, Rohde 1997, Rutherford et al. 1999). However, smaller-scale processes may also contribute, through biogeographic or ecological factors, to the regulation of diversity (Beaugrand et al. 2000b).

A comprehensive map of the mean spatial distribution of biodiversity of calanoid copepods has been recently proposed for the North Atlantic and the North Sea (Beaugrand et al. 2000b). Based on 168162 CPR samples, it was possible to detect mesoscale (ca $200 \mathrm{~km}$ ) spatial features in pelagic biodiversity at an oceanic basin level for the first time. In addition, each month and time of day were considered, with the same weight, to eliminate spatial difference due to the temporal heterogeneity of sampling. Results have demonstrated a pronounced local variability and an eastwest asymmetry in the spatial patterns of diversity of calanoid copepods. In the present study, we examine spatial changes in the diversity of this taxonomic group more finely by combining a diversity index and multivariate techniques. Principal components analysis (PCA) was used: (1) to detect the average locations of ecological regions and boundaries over the North Atlantic, (2) to identify regions with a distinct seasonal and day-night pattern, and (3) to statistically model seasonal and diel changes in diversity in this region. On the basis of these results, we outline a partition scheme for the North Atlantic. Finally, the results are discussed in a global context demonstrating the importance of the North Atlantic Current and the European Continental Shelf Current in the maintenance and regulation of diversity in the North Atlantic Drift Province.

\section{MATERIALS AND METHODS}

The Continuous Plankton Recorder (CPR) survey is an upper-layer plankton monitoring programme in the North Atlantic and North Sea based on consistent methods of sampling and analysis of plankton since 1948 (Warner \& Hays 1994). Sampling is carried out by a high-speed plankton recorder (ca $20 \mathrm{~km} \mathrm{~h}^{-1}$ ) that is towed behind voluntary merchant ships at a standard depth of ca $6.5 \mathrm{~m}$ (Hays \& Warner 1993). Plankton is filtered by a slowly moving band of silk with an average mesh size of $270 \mu \mathrm{m}$ taking samples corresponding to approximately $3 \mathrm{~m}^{3}$ of seawater filtered per sample (Hays 1994). Methods of counting and data-processing have been described by Colebrook $(1960,1975)$ and Warner \& Hays (1994).

Calanoid copepods (108 taxa) were selected because of their key position in the food web (e.g. Williams et al. 1994) and because CPR sampling and identification are optimal with these taxa. Indeed, in most cases (92.5\%) the organisms can be identified to species level, except for small calanoids for which identification is limited to genus level, and Para-Pseudocalanus which are not distinguished in routine analysis. Even though this group combines species (mainly Pseudocalanus elongatus and Paracalanus parvus) which may display different behaviour at diel and seasonal scales, we chose to keep this group because it represents a major component of the plankton diversity in the survey area. Data (168 162 samples) from January 1958 to December 1997 have been used, as the taxonomic resolution of analysis remained unchanged over this period.

Data in the CPR database are coded in such a way that local time is known for each sample. In this present work, we have directly used this information. For each of the 168162 samples, diversity as the average number of taxa per CPR sample (i.e. taxonomic richness for each CPR sample) was first calculated. We used this qualitative index as some rare taxa (e.g. Candacia varicans, Heterostylites longicornis) are recorded as presence/absence in the CPR database. Data was then clustered by $2 \mathrm{~h}$ periods from 0:00 to 24:00 h for each month, integrating $40 \mathrm{yr}$ sampling. Thus, 144 subgroups of data were constituted $(12 \mathrm{mo} \times 12$ two $\mathrm{h}$ periods). For example, Subgroup 5 contained all CPR data for 10:00 to 12:00 $\mathrm{h}$ in January.

Another problem arose from the spatial heterogeneity of the CPR sampling. The number of samples and their locations vary between regions. Spatial regularisation for each subgroup of samples was thus needed. This was achieved by an inverse square-distance interpolation method (Lam 1983). Latitude and longitude were transformed to conical Lambert coordinates (Planque et al. 1997), an equal-area polar projection that allowed surfaces on the map to be proportional to actual surfaces over the survey area and thus avoided a strong alteration of distances on the map (Richardus $\&$ Adler 1972). A grid of $50 \times 50 \mathrm{n}$. mile was selected, and interpolation of diversity value was made by using a search radius of $250 \mathrm{n}$. mile. As the diversity index we used is very sensitive to sample size, the number of neighbours selected is constant throughout each map and equal to 10 . If $<10$ neighbours were found inside the search area, no estimation of diversity was performed; if $>10$ neighbours were detected, the 10 nearest were used to estimate the number of taxa (Beaugrand et al. 2000b). The resulting 144 matrices were combined to construct a general data table within which each row denotes a geographical location and each column a $2 \mathrm{~h}$ period for a specific month.

This general data table was analysed using PCA. Firstly, from each diversity value of the general data table we subtracted the mean diversity value of its column. As the general data table was homogeneous, 
it was not divided by the standard deviation. Thus, this analysis was computed on a variance-covariance matrix of $1046 \times 1046$ pixels. Secondly, the most important eigenvectors and principal components were examined with the aim of detecting major different regions over the North Atlantic and the North Sea and monthly and diel patterns of diversity. Finally, values of diel and seasonal variations were re-estimated from the first 4 eigenvectors and principal components. This step allowed elimination of the non-explicative variability, which may have been related to the characteristics of the CPR sampling, the well-known patchy distribution of calanoid copepods, or to some year-to-year differences in the boundaries between different regions.

Seasonal changes were examined by considering day (light) and night (dark) periods separately. As these vary seasonally and with latitude (Fig. 1), only $2 \mathrm{~h}$ periods of the dark or the light periods for the whole area were selected to characterise the seasonal cycle of calanoid diversity (Fig. 1). A slight overlapping of both the sunrise and sunset times and the selected $2 \mathrm{~h}$ periods occurred in June at about $64^{\circ} \mathrm{N}$. However, cluster analyses (not shown) for each month demonstrated that this feature had no significant influence on spatial changes in diversity at a diel or monthly scale.

\section{RESULTS}

Fig. 2 maps the first 4 eigenvectors (EV 1 to 4 ) and shows monthly and diel changes from January to December of the corresponding principal components (PC 1 to 4), based on the integration of 40 yr CPR sam-

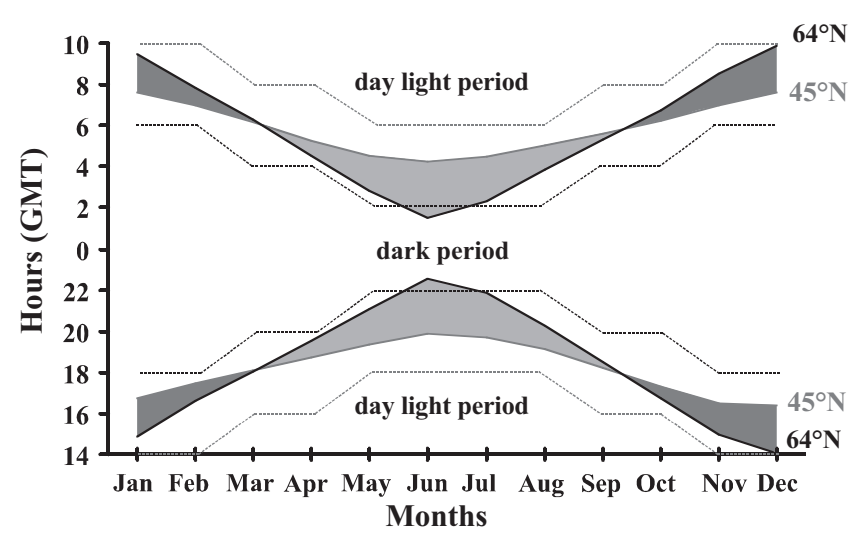

Fig. 1. Seasonal changes in daylight and dark periods. Hours (Greenwich Mean Time) of sunset and sunrise are indicated for latitudes $45^{\circ} \mathrm{N}$ (continuous black lines) and $64^{\circ} \mathrm{N}$ (continuous grey lines). Shading denotes latitudinal variations in sunset and sunrise times; black dashed lines indicate $2 \mathrm{~h}$ periods selected for examination of seasonal variations in diversity at night, grey dashed lines denote $2 \mathrm{~h}$ periods selected for examination of seasonal variations in diversity during day pling and representing a total explained variance of $62.95 \%$. The monthly and diel plots of the first principal component (Fig. 2A, 47.83\%) shows strong diel variations throughout the year. These diel changes were more pronounced from April to October. Seasonal variations were also detected, but were weaker than diel changes. Minimum values and intensity of the diel variations were recorded during winter. As the first eigenvector (EV1) is only composed of positive values, high values (in red on EV1 in Fig. 2A) indicate regions where monthly and diel changes were followed. This pattern was mainly present in the southwestern part of the North Atlantic Drift Province, as defined by Longhurst (1998).

PC2 (Fig. 2B, 8.36\%) highlights seasonal changes in diversity, although diel variations are still clearly detectable for almost all months. Diel changes appeared to be stronger in spring, autumn and winter and weaker in summer. The corresponding eigenvector (EV2, Fig. 2B) displays both negative and positive values. High negative values should be negatively related to the PC2 signal and high positive values should be positively related to the eigenvector elements. Thus, the northern part of the North Atlantic Drift Province, the southern part of the Atlantic Subarctic Province and the North Sea displayed large seasonal changes in diversity (with high values mainly in summer) and weaker diel changes. In contrast, regions south of $50^{\circ} \mathrm{N}$ displayed high diversity mainly in spring, with higher diel variations.

PC3 (Fig. 2C, 4.59\%) shows the seasonal contrast between spring and autumn months. The high negative values of EV3 (Fig. 2C) in the Bay of Biscay region were related to high negative PC3 values (and also high diversity) during spring, and the high positive values in the Gulf Stream extension reflected high PC3 values (and also high diversity) mainly during autumn. Diel changes were detectable for these periods and regions.

PC4 (Fig. 2D, 2.17\%) reveals 2 seasonal strongly positive periods in March and April and in July to October. May, June and the winter months were characterised by high negative values. Examination of EV4 shows this pattern to be positively related to the Iberian coast region. Examination of the original matrix showed that PC4 corresponds to seasonal variations in diversity in this region.

The original matrix was re-estimated using the first 4 eigenvectors and principal components that accounted for $62.95 \%$ of the total variance. Examination of residual variation $(37.05 \%$, not shown) revealed no clear spatial pattern, indicating that the first 4 principal components provide a relatively accurate model of diel and seasonal variations in diversity. The recalculated matrix was of great advantage for showing diel and 

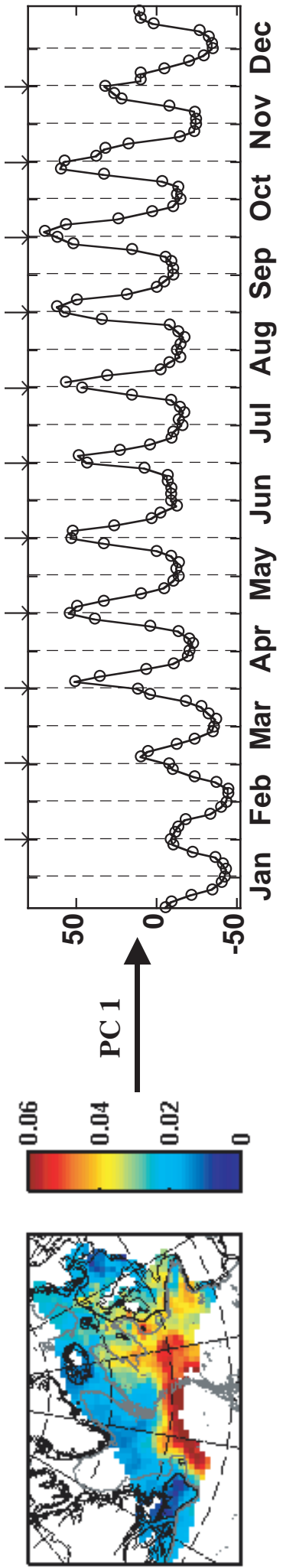

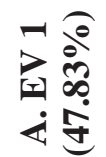
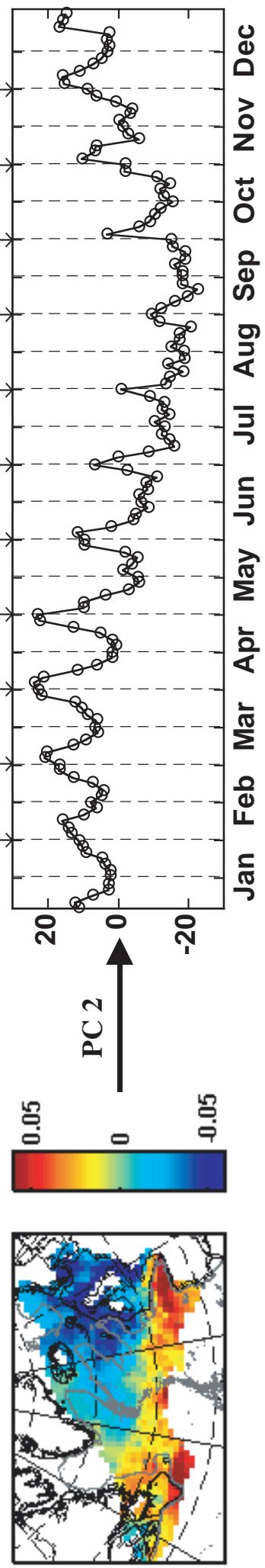

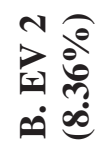
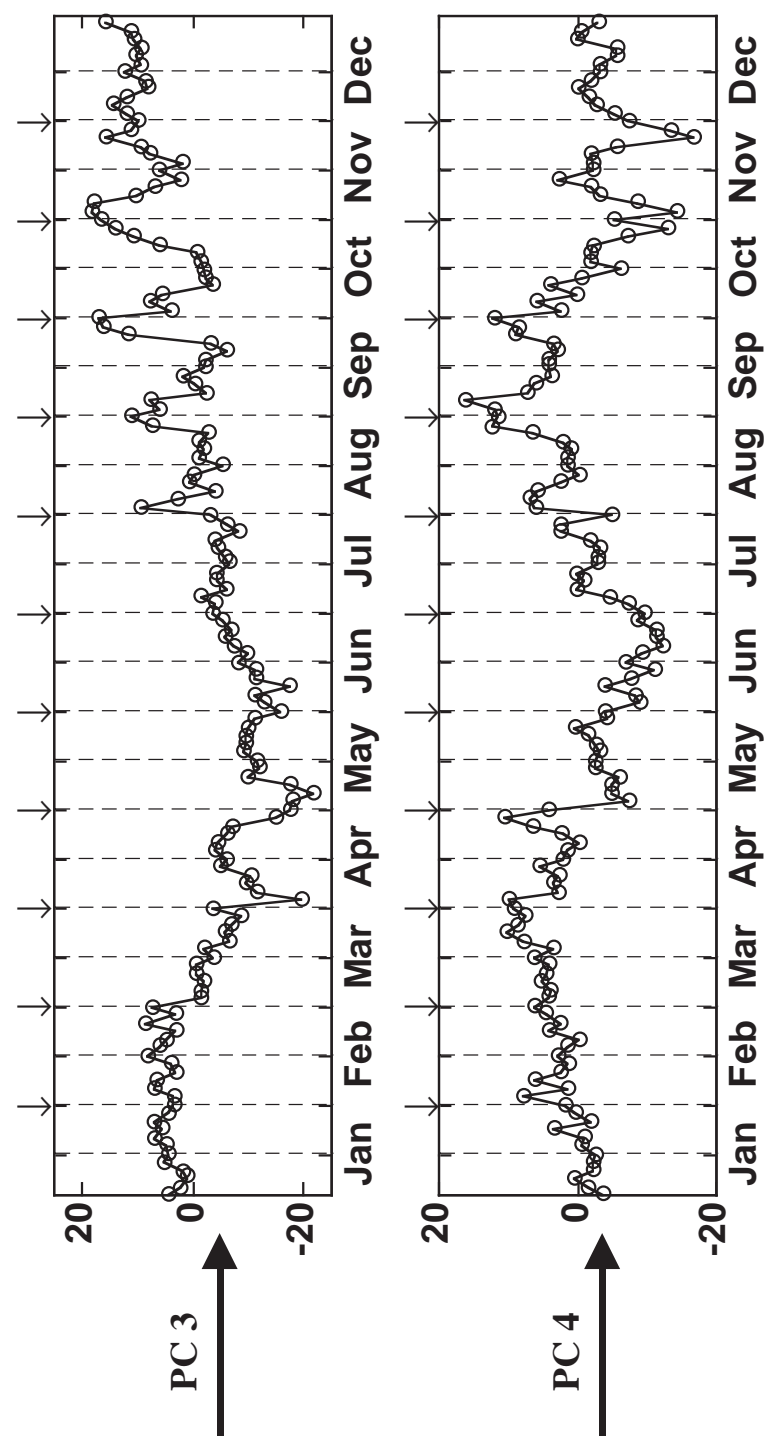

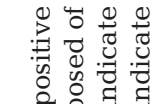

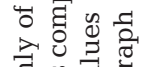

ปี

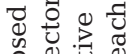

ㄴ.

- 0.00

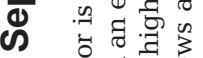

일 矛要者完

可羊苞

वै

둴 명 영

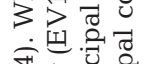

을. 青

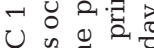

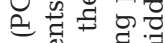

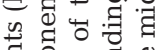

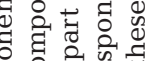

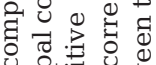

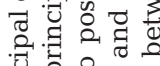

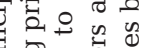

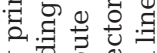

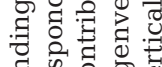

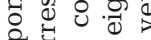

क्ष

oี

펵ㅇㅎㅇ 명

os

ซี ซี

б

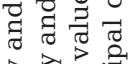

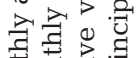

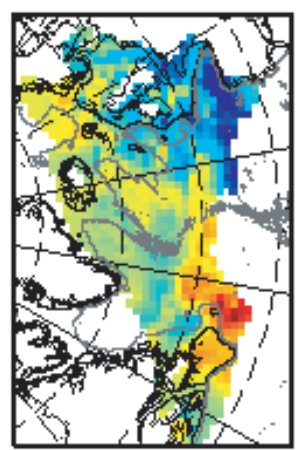

के

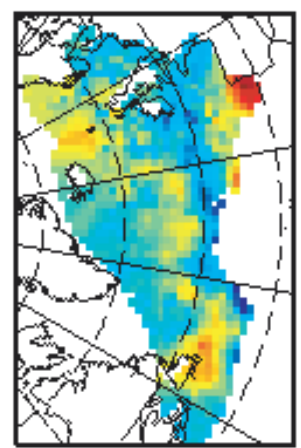

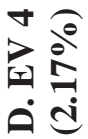

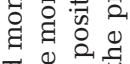

च

का

ㅇำ

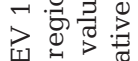

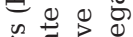

원

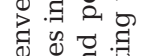

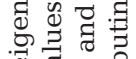

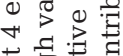

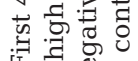

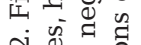

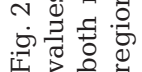


seasonal variations. The unexplained variance (37.05\%) may mainly have been due to the well-known patchy distribution of calanoids, the CPR sampling method or the integration of $40 \mathrm{yr}$ CPR sampling; some anomalous years may have contributed to an increase of variance. Thus, elimination of this unexplained variance allowed seasonal and diel patterns in diversity to be clarified.

Fig. 3 shows diel patterns in taxonomic diversity for calanoids in the North Atlantic and North Sea. From $0: 00$ to $4: 00 \mathrm{~h}$ and from 20:00 to $24: 00 \mathrm{~h}$ (periods $0: 00-2: 00,2: 00-4: 00,20: 00-22: 00,22: 00-24: 00$ h), a south-north difference occurred with higher diversity in south. An east-west difference was also apparent between 50 and $60^{\circ} \mathrm{N}$ as high diversity spread further north in the east. Diversity was especially high over the Gulf Stream extension and the Bay of Biscay. Southeast North Sea diversity is less elevated than for these 2 areas. The periods 4:00-6:00 and 18:00-20:00 h were still characterised by high diversity in the Bay of Biscay and the Gulf Stream extension, although this decreased elsewhere. From 6:00 to 18:00 h (periods 6:00-8:00, $8: 00-10: 00,10: 00-12: 00,12: 00-14: 00,14: 00-16: 00$, 16:00-18:00 h), the southeast North Sea was characterised by a higher taxonomic diversity. Diversity was also higher over the European shelf break, although this phenomenon was not evident on the American side. The difference between diurnal and nocturnal taxonomic richness increased with decreasing latitude in the survey area: Fig. 4 shows the degree of diel variation in taxonomic diversity, corroborating the difference and highlighting the contrast between continental shelves and the open ocean. Diel variation was particularly weak in the southeast North Sea, the American continental shelf, the European shelf break and off northwest Portugal, and was highest in the Gulf Stream extension to $20^{\circ} \mathrm{W}$ in the southern part of the study area.
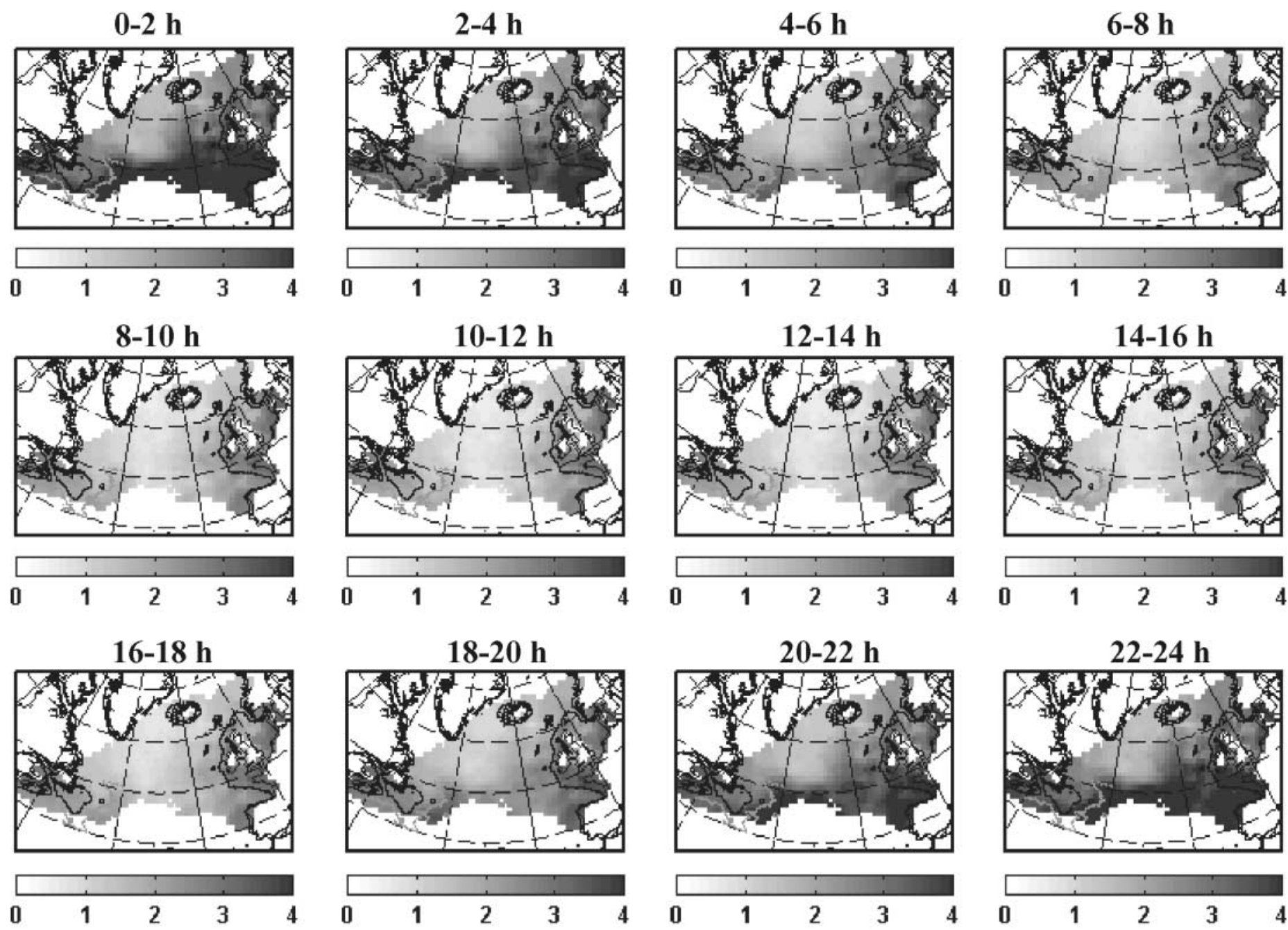

Fig. 3. Re-estimated diel changes in diversity of calanoids from first 5 principal components, which allowed unexplained variance to be removed and better detection of the diel signal. Average values, based on integration of all months. Units are mean number of taxa per CPR sample 

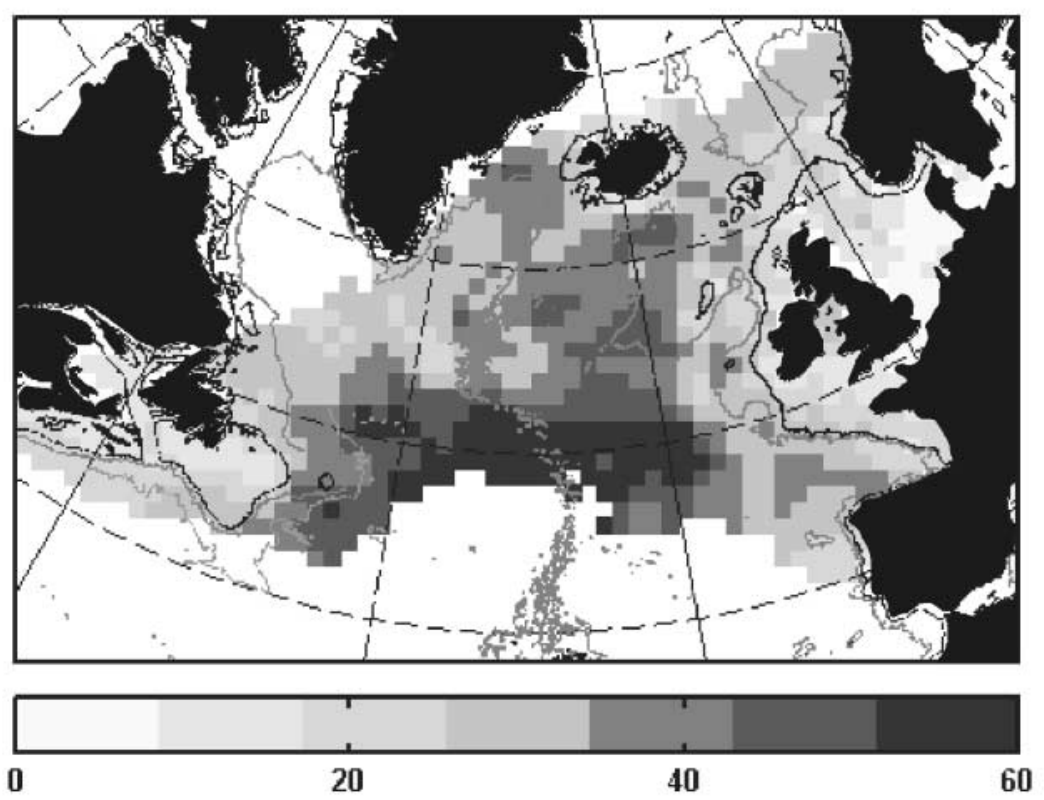

Fig. 4. Coefficient of variation (\%) of diversity of calanoids within each pixel (calculated from matrix used to represent diel changes in Fig. 3), indicating regions where diel variation was highest
The strong contrast between day and night indicated a need to interpret diurnal and nocturnal seasonal changes in diversity separately. Fig. 5 shows seasonal patterns in diversity using only nocturnal data from the reestimated matrix (see Fig. 1). In January, diversity was higher in the Bay of Biscay and over the Gulf Stream extension. This pattern was strengthened in February and March. In April, all the southern parts of the studied area had a high diversity. This pattern was similar in May and June, although slightly decreasing in intensity for all regions and especially over the North American continental shelf. East of the MidAtlantic Ridge, high diversity started to spread northwards. From July to September, diversity clearly increased northwards between $20^{\circ} \mathrm{W}$ and the European continental shelf. During this
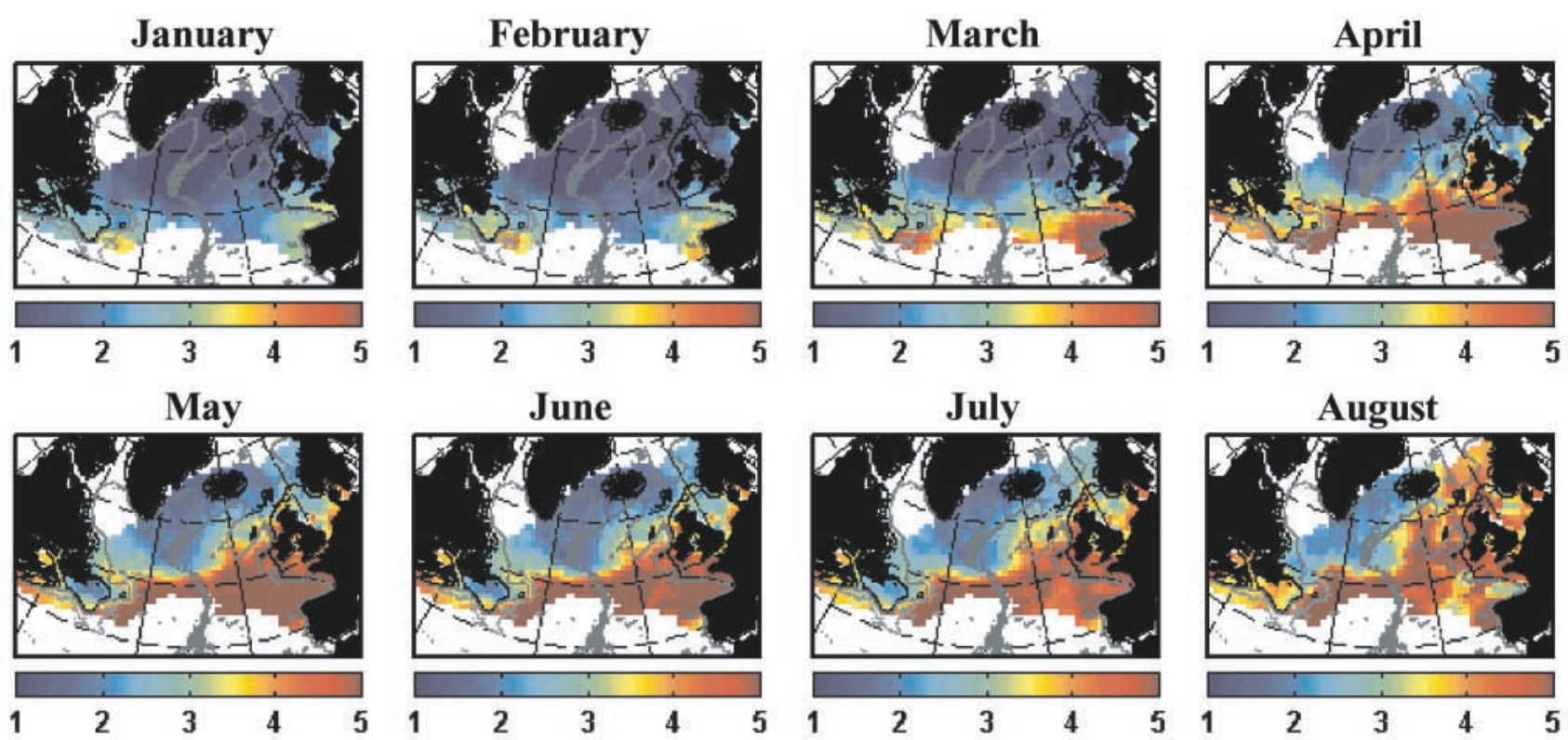

September
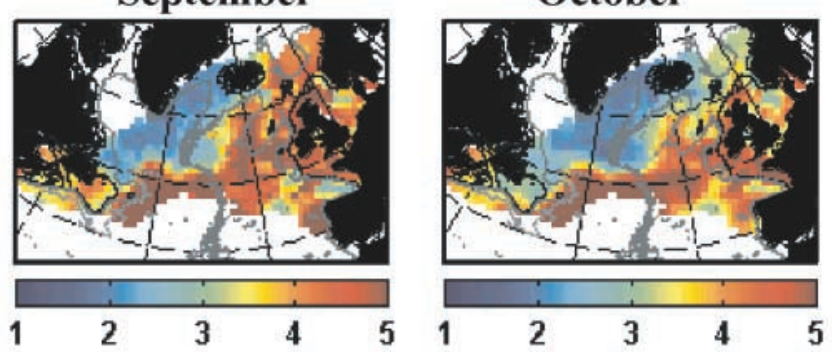

November

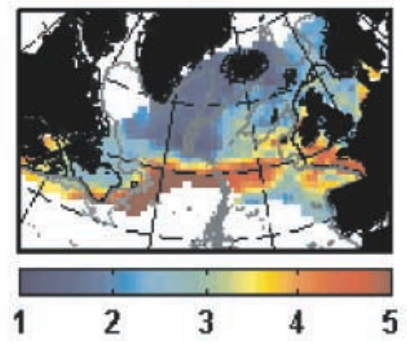

December

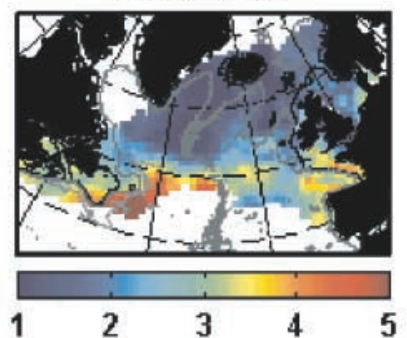

Fig. 5. Seasonal variations in diversity of calanoid copepods in night samples re-estimated from first 5 principal components. Average values, based on night samples (20:00 to 4:00 h) only. Units are mean number of taxa per CPR sample 
period, diversity was still low over the Newfoundland shelf. From October to December, diversity declined in northern areas, although it slightly increased south of Newfoundland. In December, it was still high over the Gulf Stream extension current. Fig. 6 indicates that seasonal variation was much greater north of $55^{\circ} \mathrm{N}$ in the northern part of the North Atlantic Drift Province and the Atlantic Subarctic province (as defined by Longhurst 1998). It remained especially low over the American continental shelf and to the southwest of Greenland. Low seasonal variations occurred over the Celtic Shelf break and to the southeast of the North Sea.

\section{DISCUSSION}

For pelagic taxa, global-scale patterns such as latitudinal gradients have been documented using taxa such as Foraminifera, Ostracoda, Euphausiacea, Decapoda and Pisces (Stehli et al. 1969, Reid et al. 1976, Angel 1993, Pierrot-Bults 1997). However, these patterns are far from constituting a cline of continual decrease in the number of species from the equator to the pole. Numerous tropical-polar gradients show a maximum not at the equator but to either side of it (Angel 1993, Rosenzweig \& Abramsky 1993). Ruddiman (1969), investigating foraminiferan biodiversity in the North Atlantic, stressed that the diversity gradient
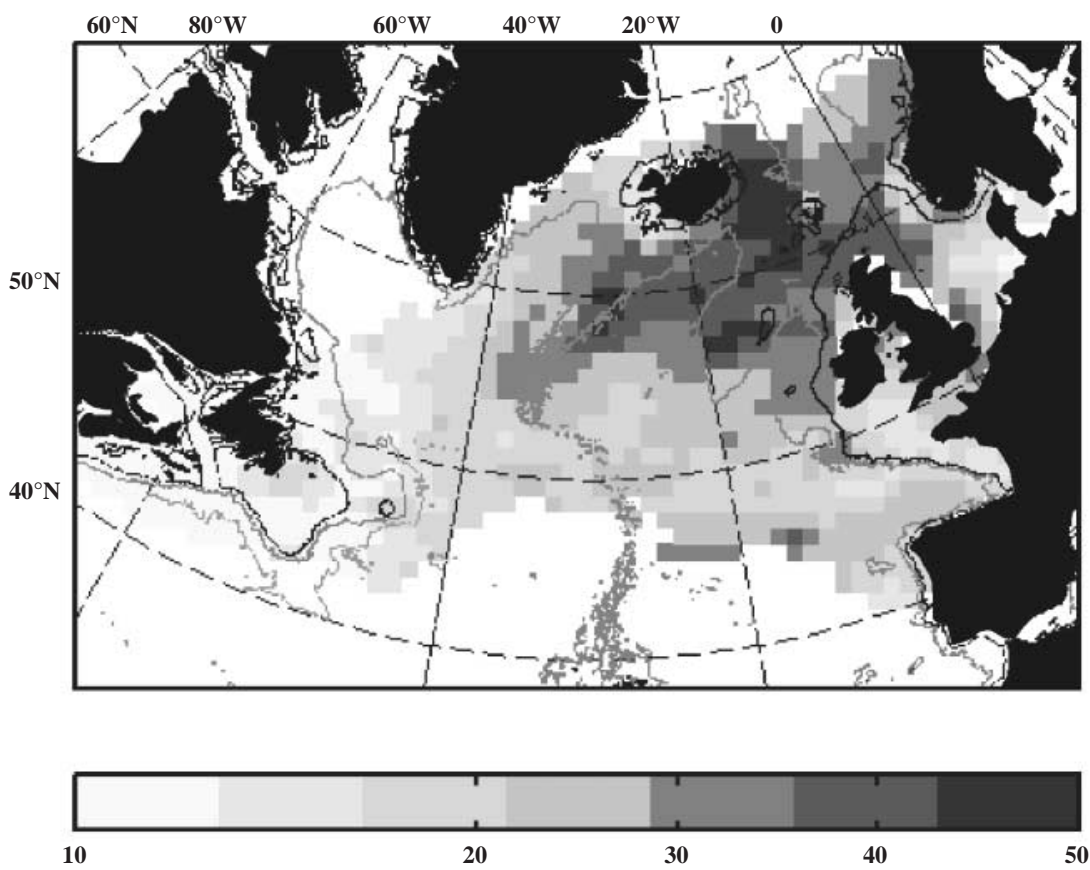

Fig. 6. Coefficient of variation (\%) of diversity of calanoids within each pixel (calculated from matrix used to represent seasonal changes [night samples] in Fig. 5), indicating regions where daily variation was highest was virtually erased by the strength of the diverse Subtropical North Atlantic Gyre. On a global scale, Rutherford et al. (1999) recently demonstrated that the diversity of Foraminifera is maximum in middle latitudes, minimum in high latitudes, and intermediate at the equator.

Our study covered an area ranging from 40 to $67^{\circ} \mathrm{N}$. Thus, our perception of this cline is limited to the extreme northward extension of the Subtropical North Atlantic Gyre, the Atlantic Polar and Subpolar Province and the transitional region between them. Nevertheless, the effects of the polar-tropical difference in diversity was clearly evidenced by this study (see for example Fig. 3). The results, however, also revealed a pronounced local spatial variability and a clear east to west asymmetry in the spatial distribution of taxonomic richness. The use of multivariate analysis in conjunction with a diversity index (here, the number of taxa per CPR sample) allowed separation of the spatial distribution of the diversity at diel and seasonal scales as well as partitioning of the North Atlantic and the North Sea. This partition will be discussed in relation to the hydrography, topography, seasonal and diel changes and the biogeochemical provinces recently proposed by Longhurst (1998). Table 1 summarises the main characteristics of the regions described in the following discussion.

\section{The Gulf Stream extension region}

The Gulf Stream extension is the region with the highest diversity in the study area (Figs 3 \& 5, and Beaugrand et al. 2000b). The centre of this region is relatively small, ranging from 43 to $50^{\circ} \mathrm{N}$ and from 40 to $48^{\circ} \mathrm{W}$ (Fig. 2C). The northern boundary of this tongue of high diversity lies between 47 and $52^{\circ} \mathrm{N}$ when seasonal fluctuations are considered (Fig. 5). High diversity originates from the hydrographical processes associated with the northern branching of the Gulf Stream. Fig. 7 shows the major surface currents over the North Atlantic from a compilation of recent works. The North Atlantic Current (NAC) flows from $42^{\circ} \mathrm{N}, 48^{\circ} \mathrm{W}$ along the Canadian Continental shelf going along the $4000 \mathrm{~m}$ isobath as far as Flemish Cap $\left(47^{\circ} \mathrm{N}, 45^{\circ} \mathrm{W}\right.$; Käse \& Krauss 1996). It then leaves the continental shelf, reaching its northernmost extremity in an area called 'the Northwest Corner' $\left(51^{\circ} \mathrm{N}\right.$, $44^{\circ} \mathrm{W}$; Worthington 1976). Subsequently, 


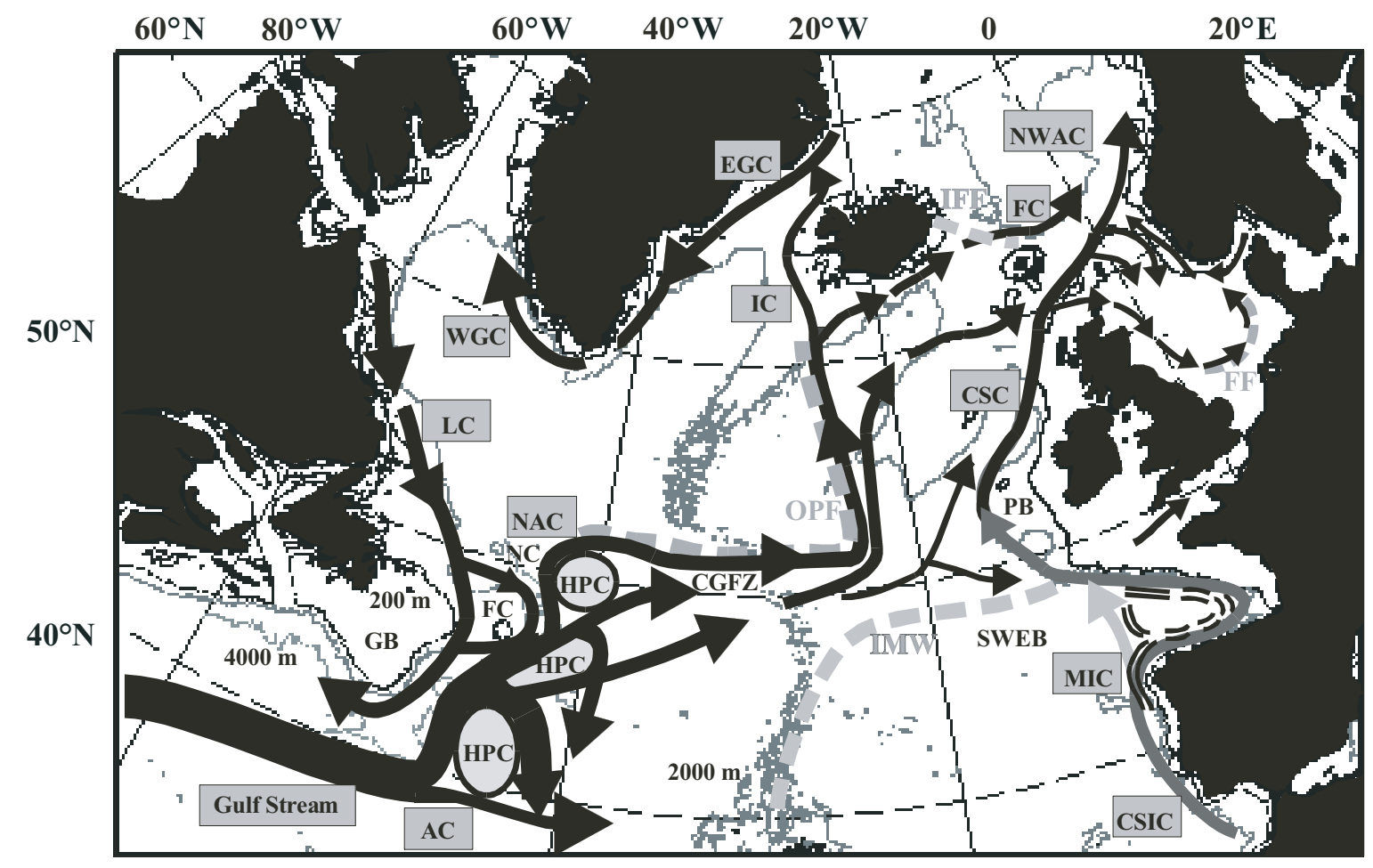

Fig. 7. Schematic representation of main surface and intermediate currents over North Atlantic based on compilation of findings or reviews from Krauss (1986), Sy (1988), Sy et al. (1992), Schmitz \& McCartney (1993), Käse \& Krauss (1996): Gulf Stream and the North Atlantic Current; van Aken \& Becker (1996), Hansen \& Osterhus (2000): northeastern currents; Madelain \& Kerut (1978), John et al. (1998), Pingree \& Le Cann (1990), Pingree (1993), Richardson et al. (2000): Bay of Biscay region; Ikeda et al. (1996), Petrie \& Buckley (1996), Han \& Tang (1999): Canadian region; Pingree et al. (1978), de Wilde et al. (1992): North Sea region. Currents = AC: Azores Current; CSC: Continental Shelf Current; CSIC: Continental Shelf Intermediate Current; EGC: East Greenland Current; FC: Faroe Current; IC: Irminger Current; LC: Labrador Current; MIC; Mediterranean Intermediate Current; NAC: North Atlantic Current; NWAC: Norwegian Atlantic Current; WGC: Western Greenland Current. Frontal structures = FF: Flamborough Front; IFF: Iceland-Faroe Front; OPF: Oceanic Polar Front. Other abbreviations = CGFZ: Charlie Gibbs Fracture Zone; FC: Flemish Cape; FF: Flamborough Front; GB: Grand Banks; HPC: High Pressure Cells; IMW: northern boundary of the influence of Mediterranean Water (1100 m of depth); NC: Northwest Corner; PB: Porcupine Bank; SWEB: South-West European Basin

it flows towards the Mid-Atlantic Ridge. Between the beginnings of the NAC and Flemish Cap, anticyclonic eddies occur, associated with high pressure cells (Käse \& Zenk 1996). This pattern occurs when there is only 1 pressure cell along the Newfoundland ridge from 40 to $50^{\circ} \mathrm{N}$, but the pressure cell can subdivide and open other water gateways eastwards (Fig. 7). Thus, the North Atlantic Current can diverge from the Canadian Continental shelf at Flemish Cap or even further southwards (Fig. 7), with a significant flow on the eastern flank of the cell turning southwards again and joining the Azores Current. This process could explain why the high diversity in this region is so restricted south of the Oceanic Polar Front (Figs 2C \& 5). Considering only the EV3 and PC3 results (Fig. 2C), the northern limit of this high diversity with its associated temporal pattern seems to be localised more at Flemish Cap than at the Northwest Corner. This is consistent with high diversity in this latter region being connected only with sporadic occurrences of the NAC (Käse \& Zenk 1996). Our results, reinforced by results of hydrographic studies, clearly indicate that this small area differs significantly from the North Atlantic Drift Province (NADR). Käse \& Krauss (1996) suggested that this area may be a direct continuation of the Atlantic Subtropical Gyre, and we propose that it be separated from the NADR to the west. The area probably corresponds to the northeastern part of the Gulf Stream extension province proposed by Longhurst (1998). However, examination of seasonal charts (Fig. 5) shows that the Northwest Corner clearly represents the northwest boundary for the seasonal spatial extension of high diversity. There is great similarity between these results and the recent map of eddy kinetic energy presented by Ducet et al. (2000).

Other processes may also contribute to enhanced diversity in this region. The path of the NAC along the Newfoundland ridge marks the separation between 
Table 1. Diel and seasonal changes and abiotic factors characteristic of regions discussed in text. Boundaries are arbitrary and regions often overlap (see Figs. 2 to 7). Some regions are clearly definable only at specific periods of time (e.g. West European Basin) while others are more constant on both seasonal and diel scales (e.g. Atlantic Arctic Province). The general term 'regions' is used to avoid the word 'ecosystem', the usefulness and relevance of which for the pelagic are debatable (e.g. van der Spoel 1994). Effects of large-scale factors responsible for tropical-polar difference in diversity (e.g. latitudinal variation in energy, and historical factors) are not shown

\begin{tabular}{|c|c|c|c|c|c|}
\hline $\begin{array}{l}\text { Provinces } \\
\text { (as defined by } \\
\text { Longhurst 1998) }\end{array}$ & $\begin{array}{l}\text { Regions identified } \\
\text { in present study }\end{array}$ & $\begin{array}{l}\text { Changes in diversity } \\
\text { Seasonal }\end{array}$ & Diel & Main abiotic characteristics & Figs \\
\hline $\begin{array}{l}\text { Gulf Stream; } \\
\text { North Atlantic } \\
\text { Drift }\end{array}$ & $\begin{array}{l}\text { Gulf Stream } \\
\text { extension } \\
\left(43-52^{\circ} \mathrm{N}, 40-48^{\circ} \mathrm{W}\right)\end{array}$ & $\begin{array}{l}\text { Slight, maximum in autumn. } \\
\text { Diversity still high in winter } \\
\text { compared to other regions }\end{array}$ & Strong & $\begin{array}{l}\text { High subtropical influence and } \\
\text { strong hydrodynamic processes }\end{array}$ & $\begin{array}{l}2 \mathrm{C}, 3,3 \\
4,5,6,7\end{array}$ \\
\hline $\begin{array}{l}\text { North Atlantic } \\
\text { Drift }\end{array}$ & $\begin{array}{l}\text { Southwest North } \\
\text { Atlantic Drift } \\
\text { (south of } 53^{\circ} \mathrm{N} \text {, } \\
\text { west to } 20^{\circ} \mathrm{W} \text { ) }\end{array}$ & $\begin{array}{l}\text { Medium, } \\
\text { maximum in autumn }\end{array}$ & Strong & High hydrodynamic processes & $\begin{array}{l}2 \mathrm{~A}, 3,4 \\
5,6,7\end{array}$ \\
\hline $\begin{array}{l}\text { North Atlantic } \\
\text { Drift }\end{array}$ & $\begin{array}{l}\text { Southeast North } \\
\text { Atlantic Drift (south } \\
\text { of } 53^{\circ} \mathrm{N} \text {, east to the } \\
\text { Mid-Atlantic Ridge) }\end{array}$ & $\begin{array}{l}\text { Medium, } \\
\text { maximum in spring }\end{array}$ & Medium & $\begin{array}{l}\text { Low hydrodynamic processes, } \\
\text { spread of Intermediate } \\
\text { Mediterranean Water }\end{array}$ & $\begin{array}{l}2 \mathrm{C}, 3,4 \\
5,6,7\end{array}$ \\
\hline $\begin{array}{l}\text { North Atlantic } \\
\text { Drift }\end{array}$ & $\begin{array}{l}\text { Northern North } \\
\text { Atlantic Drift (north } \\
\text { of } 53^{\circ} \mathrm{N} \text {, east of the } \\
\text { Mid-Atlantic Ridge }\end{array}$ & $\begin{array}{l}\text { Strong, } \\
\text { maximum in summer }\end{array}$ & Weaker & $\begin{array}{l}\text { High seasonal variability in } \\
\text { sea-surface temperature }\end{array}$ & $\begin{array}{l}2 . \mathrm{B}, 3,4 \\
5,6,7\end{array}$ \\
\hline $\begin{array}{l}\text { Northeast } \\
\text { Atlantic Shelves; } \\
\text { North } \\
\text { Atlantic Drift }\end{array}$ & $\begin{array}{l}\text { European } \\
\text { Continental } \\
\text { Shelf Break and } \\
\text { Bay of Biscay }\end{array}$ & $\begin{array}{l}\text { Weak (stronger to north), } \\
\text { maximum from March } \\
\text { (south) to September (north) }\end{array}$ & $\begin{array}{l}\text { Weak } \\
\text { (slightly } \\
\text { stronger } \\
\text { to south) }\end{array}$ & $\begin{array}{l}\text { Topography (shelf edge) } \\
\text { Shelf-edge current } \\
\text { Intermediate Mediterranean } \\
\text { Water (south of about } 50^{\circ} \mathrm{N} \text { ) }\end{array}$ & $\begin{array}{l}2 \mathrm{~B}, 3,4 \\
5,6,7\end{array}$ \\
\hline $\begin{array}{l}\text { North Atlantic } \\
\text { Subtropical } \\
\text { Gyral }\end{array}$ & $\begin{array}{l}\text { Portuguese and } \\
\text { Spanish west } \\
\text { coasts }\end{array}$ & $\begin{array}{l}\text { Strong, } \\
\text { maximum in spring } \\
\text { and autumn }\end{array}$ & $\begin{array}{l}\text { None } \\
\text { detected }\end{array}$ & Upwelling & $\begin{array}{l}2 \mathrm{~B}, 3,4 \\
5,6,7\end{array}$ \\
\hline $\begin{array}{l}\text { Northeast } \\
\text { Atlantic Shelves }\end{array}$ & North Sea & $\begin{array}{l}\text { Strong in northwest, } \\
\text { Weaker towards south } \\
\text { maximum in summer }\end{array}$ & $\begin{array}{l}\text { Stronger towards } \\
\text { north and very } \\
\text { weak in } \\
\text { southeast }\end{array}$ & $\begin{array}{l}\text { Boreal water influence to } \\
\text { northeast, coastal, warm-water } \\
\text { influence to southeast; north- } \\
\text { west influenced by advection } \\
\text { of warm North Atlantic Water }\end{array}$ & $\begin{array}{l}2 \mathrm{~B}, 3,4 \\
5,6,7\end{array}$ \\
\hline Atlantic Arctic & Atlantic Subarctic & $\begin{array}{l}\text { Medium (stronger to east), } \\
\text { maximum in late summer }\end{array}$ & Medium & $\begin{array}{l}\text { Subarctic water, } \\
\text { low hydrodynamic processes }\end{array}$ & $\begin{array}{l}3,4,5 \\
6,7\end{array}$ \\
\hline $\begin{array}{l}\text { Northwest } \\
\text { Atlantic Shelves }\end{array}$ & $\begin{array}{l}\text { Canadian Continental } \\
\text { Shelf and Slope }\end{array}$ & $\begin{array}{l}\text { Weak (stronger to east), } \\
\text { maximum in early spring } \\
\text { and late summer }\end{array}$ & Weak & $\begin{array}{l}\text { Subarctic and arctic water, } \\
\text { Labrador current, } \\
\text { eddies in south }\end{array}$ & $\begin{array}{l}3,4,5 \\
6,7\end{array}$ \\
\hline
\end{tabular}

the Labrador Current to the west and subtropical water to the east. A contrast between these water masses is particularly seen from April to December with a maximum from May to August (Fig. 5). Mixing of these water masses occurs in the Newfoundland Basin through hydrographic processes such as stirring and extrusion of cold water related to the presence of anticyclonic eddies (Käse \& Krauss 1996, Ducet et al. 2000). Subpolar species are probably imported increasing the number of taxa in this region. However, this process probably plays a minor role in comparison with the transport of subtropical species by the Gulf Stream extension.

\section{Southwest North Atlantic Drift Province}

South of $53^{\circ} \mathrm{N}$, the NADR can be subdivided into 2 by the Mid-Atlantic Ridge. In the western part (red region in Fig. 2A), the NAC spreads from the western margin of the Newfoundland basin to the Charlie Gibbs Fracture Zone (35 to $24^{\circ} \mathrm{W}, 52$ to $53^{\circ} \mathrm{N}$; Käse \& Krauss 1996). The northmost flow of the NAC is located at about 52 to $53^{\circ} \mathrm{N}$, and is closely related to the location of the Oceanic Polar Front (Sy 1988, Käse \& Krauss 1996). From EV1 (Fig. 2A) and seasonal charts (Fig. 5), it is clear that the Oceanic Polar Front acts as a barrier to the spread of calanoid diversity 
northwards. This front also corresponds to the northern boundary of the region characterised by notable diel changes and weak seasonal fluctuations in diversity (Fig. 3). Fig. 5 shows the position of this front to be seasonally stable, with its northernmost extension generally being reached from September to October.

\section{Southeast North Atlantic Drift Province (southwest European Basin)}

In the southeastern part of the NADR (blue region in Fig. 2C), a seasonal maximum in number of taxa occurs during spring, with a decrease in summer (Fig. 5). A slight increase is observed in autumn; the seasonal minimum occurs in winter. Diel changes in diversity occur from January to July, with their highest amplitude in spring. This strong contrast to the seasonal and diel variations in the area to the west of the MidAtlantic Ridge may indicate a difference in plankton composition. The southwestern part of the NADR is distinguished by strong hydrodynamic processes (Ducet et al. 2000). Conversely, the southeastern part of the NADR between the North Atlantic Current and the Subtropical Gyre tends comprise relatively slack waters (Pingree 1993). Thus, many more subtropical species must be present in the western part. This area has also been identified by Strass (1990; his Fig. 4), Weeks et al. (1993; their Fig. 14), and Campbell \& Aarup (1992; their Figs 1 \& 7). This feature was also detected by Ottens (1991), who found a different planktonic foraminiferal assemblage above and below $50^{\circ} \mathrm{N}$; he also detected another boundary at $44^{\circ} \mathrm{N}$, which is south of the area covered by the present study.

Another explanation might account for the observed differences. The area corresponds closely to the northward spreading of Intermediate Mediterranean Water (present Fig. 7, and Sy 1988, Käse \& Zenk 1996, Richardson et al. 2000). This water mass has maximum influence at $1000 \mathrm{~m}$ depth, but its range extends from 600 to $2500 \mathrm{~m}$ (Käse \& Zenk 1996). This could contribute to different patterns of diel changes. It is still questionable if such changes in the intermediate circulation would influence the biological composition of subsurface samples; however, it has been recently stressed that Calanoides carinatus may use the Mediterranean Outflow Water along the European Continental Slope (John et al. 1998, see following subsection).

\section{Northern part of North Atlantic Drift Province (above $53^{\circ} \mathrm{N}$ )}

The meridional distribution of diversity is much more variable at a seasonal scale east of the Mid-Atlantic
Ridge above $53^{\circ} \mathrm{N}$ (Figs $5 \& 6$ ). This is closely linked to spatial changes in the Oceanic Polar Front associated with a modification of the path of the NAC northwards (Fig. 7, Krauss 1986, Sy 1988). The western limit is stable at diel and seasonal scales (Figs $3 \& 5$ ). The mean northern boundary closely corresponds with the position of the branching of the NAC west of Iceland around the Reykjanes Ridge between 60 and $62^{\circ} \mathrm{N}$ (Krauss 1995). One branch flows mainly across the Iceland-Faroe Ridge toward the Norwegian Sea (van Aken \& Becker 1996), and seems to set the northern average limit of the NADR between Iceland and Faroe Islands. The other branch is the flow of the Irminger Current towards the northwest. However, no link between this current and calanoid diversity was detected. Other processes, such as forcing by temperature, might control diversity, which has a high seasonal amplitude in this area. This feature is clearly evident from Fig. 6. Examination of seasonal charts indicated that the northeastern boundary seasonally fluctuates and overflows into the Norwegian Sea in September (Fig. 5).

\section{European continental shelf break and Bay of Biscay}

That part of the European continental shelf extending from 40 to $56^{\circ} \mathrm{N}$ also has high diversity, which spreads westwards far beyond the Bay of Biscay (Beaugrand et al. 2000b). Some species display clear subtropical affinities (Poulet et al. 1996). The association of hydrodynamic processes with topography is complex in this region (Koutsikopoulos \& Le Cann 1996) and observed patterns in diversity may result from the concurrence of a large number of hydrographic processes such as wind-driven or geostrophic currents, near-surface tidal currents, undercurrents, and upwelling near the Spanish and Portuguese coasts.

Surface circulation is sluggish, and varies seasonally in the Bay of Biscay, being anticyclonic in summer and cyclonic in winter (Pingree 1993). From October to April, due to the dominance of southerly wind, a warm and saline surface current flows polewards along the Iberian coast (Pingree \& Le Cann 1990, Drago et al. 1998, Castro et al. 2000). At Cape Finisterre, this current penetrates eastwards into the southern part of the Bay of Biscay. Fernandez \& Bode (1994) reported the presence of subtropical diatoms and dinoflagellates between Cape Peñas and Cape Vidio, near the northern Spanish coast, in December 1987. They attributed this feature to an intensification of this surface current.

In contrast to surface currents, northward undercurrents are a permanent feature (Daniault et al. 1994). Between approximately 200 and $600 \mathrm{~m}$, the Intermediate Slope undercurrent flows from the equator towards the north, transporting an admixture of South Atlantic Cen- 
tral Water (John et al. 1998). This might also be a possible vector for the transport of subtropical or tropical species. At greater depth, between 600 and $1400 \mathrm{~m}$, Intermediate Mediterranean Water also flows to the north (Diaz del Rio et al. 1998). Based on multidisciplinary evidence, John et al. (1998) showed that this undercurrent could spread to the north beyond Cape Finisterre and directly join the Celtic Slope at about 47 to $48^{\circ} \mathrm{N}$, although another branch is still guided by the continental slope and enters to the south of the Bay of Biscay (Fig. 7). John et al. (1998) suggested that the spatial distribution of species able to migrate at depth (such as Calanoides carinatus in winter) is influenced by Intermediate Mediterranean Water. Species inside the $500 \mathrm{~m}$ depth water-column (such as Calanus helgolandicus) could be more influenced by the Continental Slope Current. According to John et al. (1998), this explains why the spatial distribution of Calanus helgolandicus is more restricted to the continental slope than that of Calanoides carinatus, which can cross the oceanic part from Cape Finisterre to the Celtic slope. Factors linked to life history and behaviour of organisms seem therefore to be also important in controlling of diversity in this region. Slow surface currents may also play a role in the subsequent spatial redistribution of such species in the Bay of Biscay. As observed by Hopkins et al. (1981) in the Gulf of Mexico, oceanic species may penetrate into waters over the European Continental Shelf Break and mix with neritic species. Pseudo-oceanic species recorded in this region (e.g. Calanoides carinatus, John et al. 1998, Beaugrand et al. 2000b) also increase the number of taxa.

\section{Portuguese and Spanish west coastal regions}

At latitudes off Lisbon $\left(38^{\circ} \mathrm{N}\right)$, seasonal intermittent upwelling occurs from July to September (Wooster et al. 1976). According to Colebrook (1979), they are delayed by about 1 mo northward in the region defined by EV4 and PC4 (Fig. 2D). In this region, seasonal patterns in diversity are characterised by 2 seasonal maxima, 1 in spring and the other from August to October. The second period corresponds to the timing of the intensification of the Iberian upwelling. To the north, off Cape Finisterre, the seasonal pattern in diversity has 1 maximum in spring, indicating that local upwelling has no influence on diversity at this scale.

\section{North Sea}

Examination of seasonal and diel changes (Figs 2, 3 \& 5) revealed 2 main areas in the North Sea and 2 areas representing more transitional regions between the major pelagic systems. South of the Flamborough Frontal structure, which separates seasonally thermally stratified water to the north and tidally mixed water to the south (Fig. 7, and Pingree et al. 1978), high diversity was detected (Figs 3 \& 5). This area is probably more influenced by warm Atlantic waters than boreal Atlantic water. Local conditions such as freshwater input from rivers such as the Rhine may also exert an influence (Simpson et al. 1993). This region is also distinguished by its own copepod composition. Species such as Isias clavipes are largely distributed throughout this area, although to the north their occurrence is more restricted to the coast. No clear seasonal and diel patterns were detected in the south (Figs $2 \& 3$ ). The northeast North Sea has lower diversity (Figs 3 \& 5, and Beaugrand et al. 2000b). There is a high abundance of Calanus finmarchicus in this region (Planque \& Fromentin 1996), indicating the influence of boreal water.

Between these 2 major regions, a transitional zone was detected in the Mixed Central North Sea Water (Otto et al. 1990). These 3 regions roughly correspond to the 3 major ecological subdivisions suggested by some studies based on phytoplankton (Reid et al. 1990), zooplankton (Fransz et al. 1991) and fishes (Daan et al. 1990). Examination of seasonal variability revealed a fourth region in the northwest North Sea that seems to have characteristics in common with the northern part of the North Atlantic Drift Province (Fig. 6). To the north of the Flamborough Front, the number of taxa increases from March, reaching a maximum in June to September, and then decreasing. Seasonal changes in diel variations appear to be localised after the appearance of stratification at the end of spring (de Wilde et al. 1992).

\section{Atlantic subarctic region}

Atlantic subpolar and polar regions (Longhurst 1998) have the lowest calanoid diversity in the study area (Fig. 5, and Beaugrand et al. 2000b). This characteristic is well-documented for these high-latitude areas (Richter 1994, Angel 1997, Rutherford et al. 1999), although the number of samples considered in the present analysis allowed the average boundary to be better defined. A large maximum in diversity occurs from March to December, with a peak between July and September (Fig. 5). Diel changes are detectable throughout the year, except in winter when most species such as Calanus finmarchicus overwinter at great depth (Planque \& Fromentin 1996). These seasonal and diel variations are shared with the North Atlantic Drift Province and the north and central part of the 
North Sea, indicating that diverstiy differences between all these regions are directly due to differences in the number of taxa. Many hypotheses have been proposed to explain the low diversity in polar regions, which comprises part of the large-scale tropical-polar difference in diversity (e.g. Rohde 1992, Crame 1993, Huston 1994, Rosenzweig 1995). It is not the purpose of this publication to review all of these. However, it appears that more than one hypothesis may explain the low diversity of this region. Historical factors such as the effects of the last glaciation, available energy (temperature), area and environmental stress could all possibly prevent or reduce diversity in this region.

\section{Canadian continental shelf and slope}

The Canadian continental shelf and slope display low calanoid diversity (Figs $3 \& 5$, Beaugrand et al. 2000b). The Nova Scotian shelf has permanently higher diversity in comparison to the eastern and northern parts of the Canadian shelf. Diversity on the Grand Banks is maximal from November to April and minimal in summer. To the north, diversity declines, reaching levels similar to the Atlantic Subarctic province. This region is largely influenced by the southerly Labrador Current which flows southwards along the shelf break (Han \& Tang 1999). There is a strong contrast between this region and the Gulf Stream extension to the east (Fig. 3), particularly from May to December (Fig. 5). This last feature strongly differs from that along the European continental shelf, where high diversity is localised above the slope.

\section{Seasonal and diel changes}

Four major different patterns in seasonal and diel fluctuations in the number of taxa were detected. Some similarities exist with regions detected by Campbell \& Aarup (1992) based on seasonal patterns of surface chlorophyll (Coastal Zone Color Scanner data). North of $\sim 50^{\circ} \mathrm{N}$, the seasonal pattern of diversity seems to conform to the pattern of the third region described by Campbell \& Aarup (1992) (Fig. 5). To the south of $52^{\circ} \mathrm{N}$, the seasonal pattern in diversity also matches that of chlorophyll (the second zone described by Campbell \& Aarup). However, there is a clear difference between the southeast and southwest part of the survey area, where diversity is still high in autumn and even into the winter in the Gulf Stream extension area. This latter area represents an intermediate pattern between the first and second chrorophyll pattern detected by Campbell \& Aarup (1992). Diel changes reinforce the difference between the 2 oceanic regions, and indicate the presence of distinct pelagic assemblages (Fig. 3). The fourth region corresponds to the upwelling region of the Iberian coast.

The spring bloom in the North Atlantic Drift Province was intensively studied during the North Atlantic Bloom Experiment (NABE) as part of the Join Global Ocean Flux Study (JGOFS) in 1989. Sampling was mainly along the $20^{\circ} \mathrm{W}$ meridian at approximately 47 , $52,56^{\circ}$ and $60^{\circ} \mathrm{N}$ (Ducklow \& Harris 1993, Lochte et al. 1993). At these latitudes, the spring bloom occurred in mid-April, early May, mid-May and early June, respectively (Joint et al. 1993); it was associated with increasing water stability and coincided well with modelling studies (Yentsch 1990). Reconstruction of the seasonal signal from the first 4 principal components clearly showed a large meridional variation in diversity at a seasonal scale in the North Atlantic Drift Province. Fig. 5 shows that the meridional variation below $52^{\circ} \mathrm{N}$, to the east of the Mid-Atlantic Ridge, corresponds with the onset of the spring bloom, which is linked with the start of seasonal stratification (Weeks et al. 1993). However, at 56 and $60^{\circ} \mathrm{N}$, the bloom and the increase in calanoid diversity appear to be unrelated, and there seems to be a delay of about 2 mo between bloom and the increase in diversity. This underlines the singularity of the region south of $52^{\circ} \mathrm{N}$ and east of the Mid-Atlantic Ridge.

Many factors, such as northward advection, progression of summer stratification, sea temperature or food availability may contribute to the delay between the timing of the spring bloom and the diversity maximum above $52^{\circ} \mathrm{N}$ (Carlotti et al. 1993, Planque et al. 1997, Richardson \& Verheye 1999). It is difficult to propose a reasonable explanation from the results of the present study. However, a bottom-up control of copepod diversity within the limits imposed by the thermal environment can be envisaged. The results of the NABE showed a clear change in the species contributing to primary productivity (associated with a decrease in diatoms) after the bloom (Joint et al. 1993, Weeks et al. 1993) as well as in the abundance of microzooplankton, which was found to be correlated with phytoplankton standing crop (Burkill et al. 1993). Diversity in the size fractions of the phytoplankton and microzooplankton could have increased after the bloom, and might explain why copepod diversity increased 2 mo later. Furthermore, Kleppel (1993) showed that copepods have a high dietary diversity. Kleppel \& Burkart (1995) demonstrated that dietary diversity enhanced egg production. The delay of 2 mo between the bloom and increased copepod diversity would arise from changes in community structure following diatom dominance in the first part of the spring bloom and the response to these changes by the mesozooplankton. 
Consideration of diel changes allowed discrimination between regions to be improved. Neither seasonal nor diel changes in diversity have ever been used with CPR data with the goal of identifying regions, although they comprise an important biological characteristic of pelagic ecosystems. Diel changes in diversity were more significant in the south than in the north (Figs 3 \& 4), in direct contrast to seasonal variation (Fig. 6). Throughout the southwest European basin, diel changes are clearly important in spring. In the southwest, diel changes were clearly evident throughout the year, being weaker in winter. The persistence of diel changes in winter in the south indicates overwintering of some species in the epipelagic zone in this region. In contrast, in the north there are no diel changes in winter. This difference has a strong implication for the spring bloom. Colebrook $(1979,1982)$ first suggested that the spring bloom in the North Atlantic is underexploited by grazing, a result that also emerged from the NABE (Burkill et al. 1993, Dam et al. 1993, Joint et al. 1993). Colebrook (1984) showed that south of $44^{\circ} \mathrm{N}$ grazing had a significant impact on the termination of the spring bloom in contrast to more northern areas. Our results clearly show the presence of a copepod assemblage in the epipelagic stage during winter, and thus are in agreement with Colebrook's findings. However, $50^{\circ} \mathrm{N}$ seems to be a more appropriate boundary between the 2 regions.

\section{CONCLUSION}

The combination of an index of diversity (here number of taxa per CPR sample) calculated at seasonal and diel scales and multivariate analysis (PCA) has allowed spatial decomposition of calanoid diversity, and partitioning of the North Atlantic and the North Sea has been proposed. In this region and at this scale, hydrography and topography play a major role in the regulation of diversity. Although these factors probably do not explain a large part of the tropical-polar difference in the diversity (for which energetic, geographic, historic, and environmental stress hypotheses have been proposed), they are of great importance in the spatial redistribution of diversity, which, considering the size of the spatial structures involved, probably occurs on year-to-year to multidecadal scales. Thus, detectable year-to-year or decadal changes in pelagic diversity in this region have probably already occurred, and are foreseeable in the future in response to climate changes. Considering a possible relationship between diversity and ecosystem function, which has yet to be demonstrated for the marine pelagic, although reported for other systems (e.g. Stachowicz et al. 1999, Tilman 1999), fluctuation in the diversity of calanoid copepods key group could be accompanied by major changes in the structure and functioning of ecosystems. It is expected that the flow of the North Atlantic Current and the Continental Slope Current along the European Shelf Break, which determine the transportation rate of warm water to Europe (e.g. Bigg 2000, Hansen \& Osterhus 2000) may greatly influence pelagic diversity. Thus, a modification in the path of these currents (e.g. Lehman \& Keigwin 1992) could imply marked changes in the northeastern path of the North Atlantic Drift Province, the European Shelf Break and the North Sea.

Acknowledgements. The authors are grateful to all former and present members and supporters of the Sir Alister Hardy Foundation for Ocean Science, whose continuous efforts have allowed the long-term establishment and maintenance of the CPR data-set. We are particularly grateful to P. Christopher Reid, Arnold H. Taylor, Jean-Pierre Durbec, Martin Edwards and the 3 anonymous referees for advice and comments on the manuscript. The survey depends on the owners, masters and crews of the ships that tow the CPRs. This research was supported by the European Community Research Project No. MAS3-CT98-5058, the Netherlands (SAHFOS contract RKZ595), and the French programme 'Programme National en environnement côtier, thème: influence des facteurs hydroclimatiques ou anthropiques sur la variabilité spatiotemporelle des populations et écosystèmes marins' (PNEC art 4).

\section{LITERATURE CITED}

Angel MV (1993) Biodiversity of the pelagic ocean. Conserv Biol 7:760-772

Angel MV (1997) Pelagic biodiversity. In: Ormond RFG, Gage JD, Angel MV (eds) Marine biodiversity: patterns and processes. Cambridge University Press, Cambridge, p 35-68

Beaugrand G, Ibañez F, Reid PC (2000a) Spatial, seasonal and long-term fluctuations of plankton in relation to hydroclimatic features in the English Channel, Celtic Sea and Bay of Biscay. Mar Ecol Prog Ser 200:93-102

Beaugrand G, Reid PC, Ibañez F, Planque P (2000b) Biodiversity of North Atlantic and North Sea calanoid copepods. Mar Ecol Prog Ser 204:299-303

Bigg GR (2000) Historical and potential long-term climatic change in the North Atlantic. In: Mills D (ed) The ocean life of Atlantic salmon. Environmental and biological factors influencing survival. Fishing News Books, Bodmin, UK, p 137-152

Burkill PH, Edwards ES, John AWG, Sleigh MA (1993) Microzooplankton and their herbivorous activity in the northeastern Atlantic Ocean. Deep-Sea Res Part II Top Stud Oceanogr 40:479-493

Campbell JW, Aarup T (1992) New production in the North Atlantic derived from seasonal patterns of surface chlorophyll. Deep-Sea Res 39:1669-1694

Carlotti F, Krause M, Radach G (1993) Growth and development of Calanus finmarchicus related to the influence of temperature: experimental results and conceptual model. Limnol Oceanogr 38:1125-1134

Castro CG, Pérez FF, Alvarez-Salgado XA, Fraga F (2000) Coupling between the thermohaline, chemical and bio- 
logical fields during two contrasting upwelling events off the NW Iberian Peninsula. Contin Shelf Res 20:189-210

Colebrook JM (1960) Continuous plankton records: methods of analysis, 1950-59. Bull Mar Ecol 41:51-54

Colebrook JM (1975) The Continuous Plankton Recorder survey: automatic data processing methods. Bull Mar Ecol 8: 123-142

Colebrook JM (1979) Continuous plankton records: seasonal cycles of phytoplankton and copepods in the North Atlantic Ocean and the North Sea. Mar Biol 51:23-32

Colebrook JM (1982) Continuous plankton records: seasonal variations in the distribution and abundance of plankton in the North Atlantic Ocean and the North Sea. J Plankton Res 4:435-462

Colebrook JM (1984) Continuous Plankton Records: relationships between species of phytoplankton and zooplankton in the seasonal cycle. Mar Biol 83:313-323

Crame JA (1993) Latitudinal range fluctuations in the marine realm through geological time. Trends Ecol Evol 8:162-166

Daan N, Bromley PJ, Hislop JRG, Nielsen NA (1990) Ecology of North Sea fish. Neth J Sea Res 26:343-386

Dam HG, Miller CA, Jonasdottir SH (1993) The trophic role of mesozooplankton at $47^{\circ} \mathrm{N}, 20^{\circ} \mathrm{W}$ during the North Atlantic Bloom Experiment. Deep-Sea Res II 40:197-212

Daniault N, Mazé JP, Arhan M (1994) Circulation and mixing of Mediterranean water west of the Iberian Peninsula. Deep-Sea Res 41:1685-1714

de Wilde PAWJ, Jenness MI, Duineveld GCA (1992) Introduction into the ecosystem of the North Sea: hydrography, biota, and food web relationships. Neth J Aquat Ecol 26: $7-18$

Diaz del Rio G, Gonzalez N, Marcote D (1998) The intermediate Mediterranean water inflow along the northern slope of the Iberian Peninsula. Oceanol Acta 21:157-163

Drago T, Oliveira A, Magalhães F, Cascalho J, Jouanneau JM, Vitorino J (1998) Some evidences of northward fine sediment transport in the northern Portuguese continental shelf. Oceanol Acta 21:223-231

Ducet N, Le Traon PY, Reverdin G (2000) Global high-resolution mapping of ocean circulation from TOPEX/Poseidon and ERS-1 and -2. J Geophys Res 105:19477-19498

Ducklow HW, Harris RP (1993) Introduction to the JGOFS North Atlantic Bloom Experiment. Deep-Sea Res II 40:1-8

Edinburgh Oceanographic Laboratory (1973) Continuous plankton records: a plankton atlas of the North Atlantic and the North Sea. Bull Mar Ecol 7:1-174

Fernandez E, Bode A (1994) Succession of phytoplankton assemblages in relation to the hydrography in the southern Bay of Biscay: a multivariate approach. Sci Mar 58: 191-205

Fransz HG, Colebrook JM, Gamble JC, Krause M (1991) The zooplankton of the North Sea. Neth J Sea Res 28:1-52

Han G, Tang CL (1999) Velocity and transport of the Labrador Current determined from altimetric, hydrographic, and wind data. J Geophys Res 104:18047-18057

Hansen B, Osterhus S (2000) North Atlantic-Nordic Seas exchanges. Prog Oceanogr 45:109-208

Hays GC (1994) Mesh selection and filtration efficiency of the Continuous Plankton Recorder. J Plankton Res 16:403-412

Hays GC, Warner AJ (1993) Consistency of towing speed and sampling depth for the Continuous Plankton Recorder. J Mar Biol Assoc UK 73:967-970

Hopkins TL, Milliken DM, Bell LM, McMichael EJ, Hefferman JJ, Cano RV (1981) The landward distribution of oceanic plankton and micronekton over the west Florida continental shelf as related to their vertical distribution. J Plankton Res 3:645-659
Huston MA (1994) Biological diversity. The coexistence of species on changing landscapes. Cambridge University Press, Cambridge

Ikeda M, Yao T, Yao Q (1996) Seasonal evolution of sea ice cover and shelf water off Labrador simulated in a coupled ice-ocean model. J Geophys Res C 101:16465-16489

John HC, Mittelstaedt E, Sculz K (1998) The boundary circulation along the European continental slope as transport vehicle for two calanoid copepods in the Bay of Biscay. Oceanol Acta 21:307-318

Joint I, Pomroy A, Savidge G, Boyd P (1993) Size-fractionated primary productivity in the northeast Atlantic in May-July 1989. Deep-Sea Res II 40:423-440

Käse RH, Krauss W (1996) The Gulf Stream, the North Atlantic Current, and the origin of the Azores current. In: Krauss K (ed) The warmwatersphere of the North Atlantic Ocean. Gebrüder Bontraeger, Berlin, p 292-337

Käse RH, Zenk W (1996) Structure of the Mediterranean water and Meddy characteristics in the Northeastern Atlantic. In: Krauss K (ed) The warmwatersphere of the North Atlantic Ocean. Gebrüder Bontraeger, Berlin, p 365-395

Kleppel GS (1993) On the diets of calanoid copepods. Mar Ecol Prog Ser 99:183-195

Kleppel GS, Burkart CA (1995) Egg production and the nutritional environment of Acartia tonsa: the role of food quality in copepod nutrition. ICES J Mar Sci 52:297-304

Koutsikopoulos C, Le Cann B (1996) Physical processes and hydrographical structures related to the Bay of Biscay anchovy. Sci Mar 60 (Suppl 2):9-19

Krauss W (1986) The North Atlantic current. J Geophys Res 91:5061-5074

Krauss W (1995) Currents and mixing in the Irminger Sea and the Iceland Basin. J Geophys Res 95:13089-13103

Lam NSN (1983) Spatial interpolation methods: a review. Am Cartogr 10:129-149

Lehman SJ, Keigwin LD (1992) Sudden changes in the North Atlantic circulation during the last deglaciation. Nature 356:757-762

Lindley JA (1987) Continuous plankton records: the geographical distribution and seasonal cycles of decapod crustacean larvae and pelagic post-larvae in the northeastern Atlantic Ocean and the North Sea, 1981-3. J Mar Biol Assoc UK 67:145-167

Lindley JA (1998) Diversity, biomass and production of decapod crustacean larvae in a changing environment. Invertebr Reprod Dev 33:209-219

Lochte K, Ducklow HW, Fasham MJR, Stienen C (1993) Plankton succession and carbon cycling at $47^{\circ} \mathrm{N} 20^{\circ} \mathrm{W}$ during the JGOFS North Atlantic Bloom Experiment. Deep-Sea Res II 40:91-114

Longhurst A (1998) Ecological geography of the sea. Academic Press, London

Madelain F, Kerut EG (1978) Evidence of mesoscale eddies in the Northeast Atlantic from a drifting buoy experiment. Oceanol Acta 1:159-168

Molfino B (1994) Palaeoecology of marine systems. In: Giller PS, Hildrew AG, Raffaelli DG (eds) Aquatic ecology. Scale, pattern and process. Blackwell Scientific Publications, Cambridge, p 517-546

Ottens JJ (1991) Planktic foraminifera as North Atlantic mass indicators. Oceanol Acta 14:123-140

Otto L, Zimmerman JTF, Furnes GK, Mork M, Saetre R, Becker G (1990) Review of the physical oceanography of the North Sea. Neth J Sea Res 26:161-238

Petrie B, Buckley J (1996) Volume and freshwater transport of the Labrador Current in Flemish Pass. J Geophys Res C 101:28335-28342 
Pierrot-Bults AC (1997) Biological diversity in oceanic macrozooplankton: more than counting species. In: Ormond RFG, Gage JD, Angel MV (eds) Marine biodiversity: patterns and processes. Cambridge University Press, Cambridge, p 69-93

Pingree RD (1993) Flow of surface waters to the west of the British Isles and in the Bay of Biscay. Deep-Sea Res II 40: 369-388

Pingree RD, Le Cann B (1990) Structure, strength and seasonality of the slope currents in the Bay of Biscay region. J Mar Biol Assoc UK 70:857-885

Pingree RD, Holligan PM, Mardell GT (1978) The effects of vertical stability on phytoplankton distributions in summer on the northwest European shelf. Deep-Sea Res 25: 1011-1028

Planque B, Fromentin JM (1996) Calanus and environment in the eastern North Atlantic. I. Spatial and temporal patterns of C. finmarchicus and C. helgolandicus. Mar Ecol Prog Ser 134:101-109

Planque B, Hays GC, Ibañez F, Gamble JC (1997) Large scale spatial variations in the seasonal abundance of Calanus finmarchicus. Deep-Sea Res Part I Oceanogr Res Pap 44: 315-326

Poulet SA, Laabir M, Chaudron Y (1996) Characteristic features of zooplankton in the Bay of Biscay. Sci Mar 60 (Suppl 2):79-85

Reid JL, Brinton E, Fleminger A, Venrick EL, McGowan JA (1976) Ocean circulation and marine life. In: Charnock $H_{\text {, }}$ Deacon G (eds) Advances in oceanography. Plenum Press, New York, p 65-130

Reid PC, Lancelot WWC, Gieskes E, Hagmeier E, Weickart G (1990) Phytoplankton of the North Sea and its dynamics: a review. Neth J Sea Res 26:295-331

Reid PC, Edwards M, Hunt HG, Warner AJ (1998) Phytoplankton change in the North Atlantic. Nature 391:546

Rex MA, Stuart CT, Hessler RR, Allen RR, Sanders HL, Wilson GDF (1993) Global-scale latitudinal patterns of species diversity in the deep-sea benthos. Nature 365:636-639

Richardson AJ, Verheye HM (1999) Growth rates of copepods in the southern Benguela upwelling system: the interplay between body size and food. Limnol Oceanogr 44:382-392

Richardson PL, Bower AS, Zenk W (2000) A census of Meddies tracked by floats. Prog Oceanogr 45:209-250

Richardus P, Adler RK (1972) Map projections for geodesists, cartographers and geographers. North-Holland, Amsterdam

Richter C (1994) Regional and seasonal variability in the vertical distribution of mesozooplankton in the Greenland Sea. Ber Polarforsch 154:1-87

Rohde K (1992) Latitudinal gradients in species diversity: the search for the primary cause. Oikos 65:514-527

Rohde K (1997) The larger area of the tropics does not explain latitudinal gradients in species diversity. Oikos 79:169-172

Rosenzweig ML (1995) Species diversity in space and time. Cambridge University Press, Cambridge

Rosenzweig ML, Abramsky Z (1993) How are diversity and

Editorial responsibility: Otto Kinne (Editor),

Oldendorf/Luhe, Germany productivity related? In: Ricklefs RE, Schluter D (eds) Species diversity in ecological communities. Chicago University Press, Chicago, p 39-65

Ruddiman WF (1969) Recent planktonic foraminifera: dominance and diversity in North Atlantic surface sediments. Science 164:1164-1167

Rutherford S, D'Hondt S, Prell W (1999) Environmental controls on the geographic distribution of zooplankton diversity. Nature 400:749-753

Schmitz WJ, McCartney MS (1993) On the North Atlantic circulation. Rev Geophys 31:29-49

Simpson JH, Bos WG, Schirmer F, Souza AJ, Rippeth TP, Jones SE, Hydes D (1993) Periodic stratification in the Rhine ROFI in the North Sea. Oceanol Acta 16:23-32

Stachowicz JJ, Whitlatch RB, Osman RW (1999) Species diversity and invasion resistance in a marine ecosystem. Science 286:1577-1579

Stehli FG, Douglas RG, Newell RG (1969) Generation and maintenance of gradients in taxonomic diversity. Science 164:947-949

Strass VH (1990) Meridional and seasonal variations in the satellite-sensed fraction of euphotic zone chrorophyll. J Geophys Res 95:18289-18301

Sy A (1988) Investigation of large-scale circulation patterns in the central North Atlantic: the North Atlantic Current, the Azores Current, and the Mediterranean Water plume in the area of the Mid-Atlantic Ridge. Deep-Sea Res 35: $383-413$

Sy A, Schauer U, Meincke J (1992) The North Atlantic Current and its associated hydrographic structure above and eastwards of the Mid-Atlantic Ridge. Deep-Sea Res 39: $825-853$

Tilman D (1999) The ecological consequences of changes in biodiversity: a search for general principles. Ecology 80: 1455-1474

van Aken HM, Becker G (1996) Hydrography and throughflow in the north-eastern North Atlantic Ocean: the NANSEN project. Prog Oceanogr 38:297-346

van der Spoel (1994) The basis for boundaries in pelagic biogeography. Prog Oceanogr 34:121-133

Warner AJ, Hays GC (1994) Sampling by the Continuous Plankton Recorder survey. Prog Oceanogr 34:237-256

Weeks AR, Fasham MJR, Aiken J, Harbour DS, Read JF, Bellan I (1993) The spatial and temporal development of the spring bloom during the JGOFS North Atlantic Bloom Experiment, 1989. J Mar Biol Assoc UK 73:253-282

Williams R, Conway DVP, Hunt HG (1994) The role of copepods in the planktonic ecosystems of mixed and stratified waters of the European shelf seas. Hydrobiologia 292/293: $521-530$

Wooster W, Bakun A, McLain DR (1976) The seasonal upwelling cycle along the eastern boundary of the North Atlantic. J Mar Res 34:131-141

Worthington LV (1976) On the North Atlantic circulation. Oceanogr Stud 6:1-110

Yentsch (1990) Estimates of 'new production' in the MidNorth Atlantic. J Plankton Res 12:717-734

Submitted: September 11,2000; Accepted: March 15, 2001

Proofs received from author(s): August 17, 2001 